\begin{tabular}{l|r|r}
\hline Jurnal Penelitian Keperawatan & Vol. 2 No. 1 & Edition: May - October 2019 \\
\hline \multirow{2}{*}{ Received: 09 October 2019 } & $\frac{\text { http://ejournal.delihusada.ac.id/index.php/JPKM }}{\text { Accepted: } 24 \text { October 2019 }}$ & Revised: 18 October 2019 \\
\cline { 2 - 3 } & & \\
\hline
\end{tabular}

\title{
HUBUNGAN MOBILISASI DINI TERHADAP PENYEMBUHAN LUKA POST OPERASI SECTIO CESARIA
}

\author{
Nurul Aini Siagian, Syafira Nusaibah, Andayani Boang Manalu \\ Institut Kesehatan DELI HUSADA Deli Tua, Jl. Besar Deli Tua \\ Email: nurulainisiagian@yahoo.co.id
}

\begin{abstract}
Early mobilization includes factors that can affect the process of wound healing after surgery. Immediate mobilization in stages is very useful for the process of healing wounds and preventing infection and venous thrombosis. The purpose of this study was to determine whether there is a relationship between early mobilization and the process of healing wound post operative sectio caesarea at Sinar Husni General Hospital Medan Helvetia. The research design used was analytic survey with cross sectional approach. The sample in this study used the Consecutive Sampling method of data collection using a checklist sheet conducted on a sample of 19 respondents. The results of the study in this study are the majority of respondents who did early mobilization and who experienced rapid wound healing process as many as 4 people (21\%) while the minority of respondents who did early mobilization and who experienced slow wound healing process were 1 person (5.3\%). The majority of respondents who did not mobilize early and who experienced a slow wound healing process were 11 people (57.9\%) and a minority who did not mobilize early and who experienced rapid healing as many as 4 people (21.1\%). Statistical test results obtained $p$ value $=0.046<0.005$. The conclusions of the results of this study indicate there is a relationship between early mobilization and the process of healing post operative sectio of caesarea. Suggestions The results of this study can be applied as a reference to improve nursing care services, especially in providing counseling and assistance to patients.
\end{abstract}

Keywords: early mobilization, woumd healing, post operation, sectio cesaria

\section{PENDAhUlUAN}

Menurut WHO (word health organization) setiap tahun wanita hamil berjumlah 160 juta jiwa, rata-rata $15 \%$ menderita komplikasi yang mengancam jiwa ibu yang mengakibatkan kematian lebih dari 500.000 jiwa per tahunnya, komplikasi tersebut terjadi di Asia dan Afrika subsahara terdapat $90 \%$ dan $10 \%$ di negara berkembang lainnya, penyebab langsung angka kematian ibu terjadi akibat perdarahan pasca persalinan $25 \%$, sepsis $15 \%$, hipertensi dalam kehamilan $12 \%$ partus macet $8 \%$, komplikasi abortus tidak aman $13 \%$ dan sebab- sebab lain 8\% (Prawirohardjo, 2008)
Pada tahun 2012 terdapat hasil data Angka Kematian Ibu sebanyak 359 kematian per 100.000 kelahiran hidup dan pada tahun 2015 menurun menjadi 305 kematian per 100.000 kelahiran hidup pada AKI tertinggi terdapat di wilayah Sumatera Utara, Banten, Jawa Barat, Jawa Tengah, Jawa Timur dan Sulawesi Selatan, (Kemenkes RI, 2016)

Di Indonesia pada tahun 2006 sectio caesarea masih cukup tinggi dimana pada tahun 2006 sebanyak 51.22\%, tahun 2007 sebanyak 51.51\%, tahun 2008 sebanyak $52.13 \%$, tahun 2009 sebanyak $54.87 \%$, tahun 2010 sebanyak 55.22\%, tahun 2011 sebanyak 55.59\%, tahun 2012 sebanyak 56.68\% (Anggreini, 2014)

Pada tahun 2011 angka kematian ibu yang disebabkan oleh infeksi berjumlah $5,5 \%$ dan 


\begin{tabular}{l|r|r}
\hline Jurnal Penelitian Keperawatan & Vol. 2 No. 1 & Edition: May - October 2019 \\
\hline \multirow{2}{*}{ Received: 09 October 2019 } & $\frac{\text { http://ejournal.delihusada.ac.id/index.php/JPKM }}{\text { Revised: 18 October 2019 }}$ & Accepted: 24 October 2019 \\
\cline { 2 - 3 } & & \\
\hline
\end{tabular}

meningkat 7,3\% pada tahun 2013 . Hal menunjukkan bahwa infeksi pasca salin herus ditangani dengan serius. Operasi section caesarea efek anastesi lama kelamaan akan hilang sehingga ibu akan merasakan nyeri pada luka bekas insisi abdomen, yang berpotensi terjadinya tromboemboli, thrombosis, infeksi dan lain sebagainya (Irmayanti, 2019)

Tindakan operasi sectio caesarea menyebabkan nyeri dan mengakibatkan terjadinya perubahan kontiunitas jaringan karena adanya pembedahan, nyeri yang dirasakan pada ibu yang dilakukan tindakan sectio caesarea biasanya di rasakan pada hari 1-2, dan bahkan sekitar 32\% pasien berlangsung sampai mereka pulang kerumah, dan tidak jarang pada luka setelah pulang bertambah berat sehingga membutuhkan obat analgesik (Anggoro, $\mathrm{dkk}, 2010$ )

Mobilisasi dini adalah pergerakan secara dini untuk mempertahankan kemandirian seseorang untuk membimbing penderita keluar dari tempat tidurnya seperti berjalan, menggerakkan anggota tubuh dengan cara miring kiri dan miring kanan dan membimbing pasien untuk mempertahankan fungsi fisiologisnya untuk mencegah komplikasi, pada pasien post sectio caesarea harus segera melakukan aktivitas setelah 24 jam, dan dapat menggerakkan anggota tubuh seperti tangan, jari-jari serta mengangkat kedua kaki setelah 6 jam pertama (Sumaryati, 2018)

Mobilisasi dini dapat menunjang proses penyembuhan luka pasien karena dengan menggerakkan anggota badan akan mencegah kekauan otot dan sendi, sehingga dapat mengurangi nyeri dan dapat memperlancar peredaran darah ke bagian yang mengalami perlukaan agar proses penyembuhan luka menjadi lebih cepat (Fitriani, 2017)

Berdasarkan latar belakang diatas peneliti ingin membuktikan apakah ada hubungan mobilisasi dini terhadap sembuhnya luka Post Sectio Caesarea sehingga peneliti tertarik ununtuk mengambil judul ada hubungan mobilisasi dini dengan penyembuhan luka operasi post sectio caesarea.

\section{METODE}

Metode Jenis Penelitian yang di gunakan adalah survey analitik dengan desain pendekatan cross sectional. Sampel data penelitian ini adalah semua pasien ibu melahirkan dengan tindakan operasi sectio caesarea. Dengan teknik pengambilan sampel secara Consecutive Sampling sejumlah 19 responden. Untuk menganalisis hubungan hubungan mobilisasi dini dengan penyembuhan luka operasi post sectio menggunakan uji statistik Chi Square.

\section{HASIL DAN PEMBAHASAN}

Dapat dilihat bahwa distribusi Karakteristik responden berdasarkan umur dan 19 responden mayoritas berumur 26-30 tahun sebanyak 11 orang (57,9\%) dan minoritas responden berumur $17-25$ tahun sebanyak 8 orang $(42,1 \%)$. Karakteristik responden berdasarkan pendidikan dan 19 responden mayoritas berpendidikan SMA sebanyak 6 orang $(31,6 \%)$, responden berpendidikan SD sebanyak 5 orang $(26,3 \%)$ dan minoritas responden berpendidikan SMP sebanyak 4 orang $(21,1 \%)$, responden berpendidikan S1 aebanyak 4 orang $(21,1 \%)$ lihat tabel 1.

Tabel 1. Karakteristik Umur dan Pendidikan

\begin{tabular}{lcc}
\hline \multicolumn{1}{r}{ Variabel } & Frekuensi & (\%) \\
\cline { 2 - 3 } Umur & & \\
$17-25$ & 8 & 42,1 \\
$26-30$ & 11 & 57,9 \\
Total & 19 & 100 \\
Pendidikan & & \\
SD & 5 & 26,3 \\
SMP & 4 & 21,1 \\
SMA & 6 & 31,6 \\
S1 & 4 & 21,1 \\
Total & 19 & 100 \\
\hline
\end{tabular}

Dapat dilihat bahwa mayoritas responden yang tidak melakukan mobilisasi dini sebanyak 14 orang $(73,7 \%)$ minoritas responden melakukan mobilisasi dini sebanyak 5 orang $(26,3 \%)$.

Tabel 2. Mobilisasi Dini

\begin{tabular}{cccc}
\hline No. & Mobilisasi dini & Frek & $\begin{array}{c}\text { Persentase } \\
(\%)\end{array}$ \\
\hline 1. & Dilakukan & 5 & 26,3 \\
2. & Tidak Dilakukan & 14 & 73,7 \\
& Total & 19 & 100 \\
\hline
\end{tabular}

Hal ini sejalan dengan penelitian Netty (2013), hasil observasi dari 42 responden yang melakukan mobilisasi sebanyak 33 responden dan yang sembuh lukanya sebanyak 30 responden. 


\begin{tabular}{|c|c|c|c|c|c|c|}
\hline \multirow[t]{2}{*}{ Jurnal Penelitian Keperawatan } & \multicolumn{3}{|c|}{ Vol. 2 No. 1} & \multicolumn{3}{|c|}{ Edition: May - October 2019} \\
\hline & \multicolumn{3}{|c|}{ http://ejournal.delihusada.ac.id/index.php/JPKM } & & & \\
\hline Received: 09 October 2019 & \multicolumn{3}{|c|}{ Revised: 18 October 2019} & \multicolumn{3}{|c|}{ Accepted: 24 October 2019} \\
\hline \multirow{4}{*}{\multicolumn{2}{|c|}{$\begin{array}{l}\text { menurut kasdu (2011), menyatakan mobilisasi } \\
\text { dini diawali dengan menggerakan lengan, jari-jari } \\
\text { tangan dan kaki pada } 6 \text { jam pertama setelah } \\
\text { operasi, miring kekiri kanan dan kanan dimulai } \\
\text { sejak } 6-10 \text { jam post operasi untuk mencegah }\end{array}$}} & $\begin{array}{c}\text { buhan } \\
\text { luka }\end{array}$ & ya & Tidak & & \\
\hline & & Cepat & 4 & 4 & 8 & \\
\hline & & Lambat & 1 & 10 & 11 & 0,046 \\
\hline & & Total & 5 & 14 & 19 & \\
\hline
\end{tabular}
24 jam, kemudian belajar berdiri dan belajar jalan pada pasien post sectio caesarea.

Dapat dilihat bahwa pada table diatas bahwa mayoritas responden yang mengalami proses penyembuhan luka lambat sebanyak 11 orang $(57,9 \%)$ dan minoritas responden yang mengalami proses penyembuhan luka cepat sebanyak 8 orang $(42,1 \%)$.

Tabel 3. Proses Penyembuhan Luka Operasi

\begin{tabular}{cccc}
\hline No. & $\begin{array}{c}\text { Proses } \\
\text { Penyembuhan } \\
\text { Luka }\end{array}$ & $\begin{array}{c}\text { Frekuensi } \\
\text { (f) }\end{array}$ & $\begin{array}{c}\text { Persentase } \\
\text { (\%) }\end{array}$ \\
\hline 1. & Cepat & 8 & 42,1 \\
2. & Lambat & 11 & 57,9 \\
& Total & 19 & 100 \\
\hline
\end{tabular}

Hasil penelitian ini sejalan dengan penelitian Rahmawati (2018), yang menyatakan bahwa penelitian terdapat 27 responden $(84,4 \%)$ mengalami penyembuhan luka post sectio caesarea. Hasil ini diperoleh dari pengamatan setelah 3 hari post operasi sectio caesarea dari 32 responden, dan 5 responden $(15,6 \%)$ yang lukanya tidak sembuh dengan normal. Hal ini diketahui pada saat pergantian kassa masih ditemukan luka yang basah, merah, dan terbuka atau luka tidak menyatu. Balutan luka jahitan post operasi harus diperhatikan secara rutin untuk memastikan bahwa balutan kering, utuh, dan bersih (Kozier, 2010).

Hasil analisis Hubungan Mobilisasi Dini Dengan Proses Penyembuhan Luka Post Operasi Sectio Caesarea Di RSU Sinar Husni Kabupaten Deli Serdang. Mayoritas responden yang melakukan mobilisasi dini dan yang mengalami proses penyembuhan luka cepat sebanyak 4 orang $(21 \%)$ sedangkan minoritas responden yang melakukan mobilisasi dini dan yang mengalami proses penyembuhan luka lambat sebanyak 1 orang $(5,3 \%)$.

Tabel 4. Hubungan Proses Penyembuhan dan Tindakan Mobilisasi Dini

\begin{tabular}{cccc}
\hline $\begin{array}{c}\text { Proses } \\
\text { penyem }\end{array}$ & $\begin{array}{c}\text { Tindakan } \\
\text { Mobilisasi Dini }\end{array}$ & Total & $\begin{array}{c}P \\
\text { Value }\end{array}$ \\
\hline
\end{tabular}




\begin{tabular}{l|r|r}
\hline Jurnal Penelitian Keperawatan & Vol. 2 No. 1 & Edition: May - October 2019 \\
\hline \multirow{2}{*}{ Received: 09 October 2019 } & $\frac{\text { http://ejournal.delihusada.ac.id/index.php/JPKM }}{\text { Accepted: } 24 \text { October 2019 }}$ & Revised: 18 October 2019 \\
\cline { 2 - 3 } & & \\
\hline
\end{tabular}

berpendidikan SMA sebanyak 6 orang $(31,6 \%)$, responden berpendidikan SD sebanyak 5 orang $(26,3 \%)$ dan minoritas responden berpendidikan SMP sebanyak 4 orang $(21,1 \%)$, responden berpendidikan S1 aebanyak 4 orang $(21,1 \%)$.

2. Ada hubungan hubungan mobilisasi dini dengan proses penyembuhan luka post operasi sectio caesarea dengan nilai $P$ adalah 0,046<0,005

\section{DAFTAR PUSTAKA}

Anggorowati \& Sudiharjani, Nanik. (2011). Mobilisasi Dini Dan Penyembuhan Luka Operasi Pada Ibu Post Sectio Caesarea (Sc) Di Ruang Dahlia Rumah Sakit Umum Daerah Kota Salatiga. Departemen Keperawatan Maternitas Dan Anak Ps Ilmu Keperawatan FK UNDIP

Anggriani, S., Suwandi, \& Wahyuni, S. 2014. Hubungan Mobilisasi Dini Terhadap Penyembuhan Luka Post Op Sectio Caesarea di RSUD. Salewangang Maros. Jurnal Ilmiah Kesehatan Diagnosis, Vol. 4 (5)

Irmayanti, (2019). Mobilisasi Dini Pada Proses Penyembuhan Luka Sectio Caesarea Pada Ibu Postpartum di RS Dewi Sartika. Jurnal Smart Kebidanan, Vol. 6 (1)

Kasdu. (2003). Operasi Caesar Masalah dan Solusinya. Jakarta : Puspa Swara

Kemenkes RI. (2016). Riset Kesehatan Dasar Tahun 2016. Jakarta : Kemenkes RI

Kozier. (2010). Buku Ajar Praktik Keperawatan Klinis. Edisi 5. Jakarta : EGC

Netty, I. 2013. Hubungan Mobilisasi Dini Dengan penyembuhan Luka Post Operasi Seksio Sesaria di Ruang Rawat Gabung Kebidanan RSUD. H Abdul Manap Kota Jambi. Seri Sains, Vol. 15 (1).

Prawirohardjo, S (2008). IImu Kebidanan. Bina Pustaka. Jakarta

Rahmawati \& Riski Ima, (2018). Hubungan Tingkat Pendidikan dan Riwayat Antenatal Care (ANC) dengan Tindakan Sectio Caesarea. Skripsi. Universitas Muhammadiyah Surakarta.
Sumaryati, Widodo, G.G., \& Purwaningsih, H. 2018. Hubungan Mobilisasi Dini dengan Tingkat Kemandirian Pasien Post Sectio Caecarea di Bangsal Mawar RSUD Temanggung. Indonesian Journal of Nursing Research, Vol. 1 (1). 